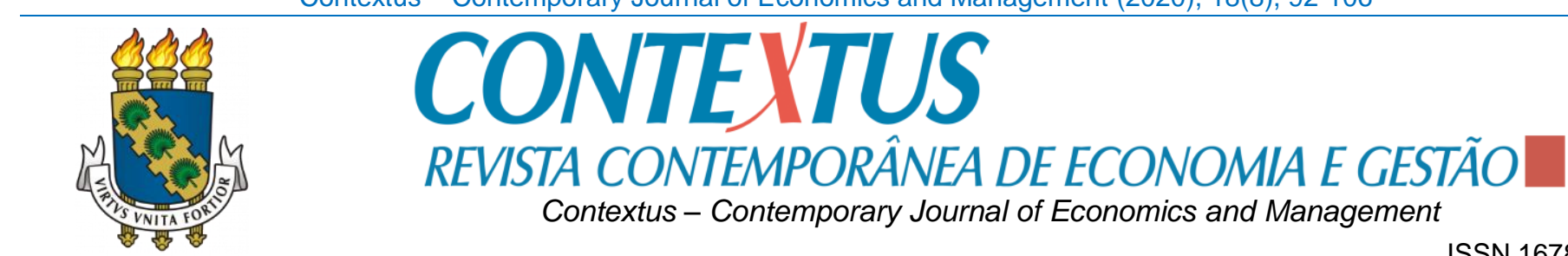

FEDERAL UNIVERSITY

ISSN 1678-2089

OF CEARÁ

www.periodicos.ufc.br/contextus

ISSNe 2178-9258

\title{
The impact of digital transformation and industry 4.0 on the aspects of value: Evidence from a meta-synthesis
}

\author{
O impacto da transformação digital e da indústria 4.0 nos aspectos de valor: Evidências de uma meta- \\ síntese
}

El impacto de la transformación digital y la industria 4.0 en aspectos de valor: evidencia de una metasíntesis

https://doi.org/10.19094/contextus.2020.43717 ${ }^{\text {d. }}$

\section{Giovani Cruzara}

https://orcid.org/0000-0001-5128-5948

PhD student in Administration at the Federal University of Paraná (UFPR)

Master in Business Administration at the Federal University of Paraná (UFPR)

giovani.cruzara@outlook.com

\section{Adriana Roseli Wunsch Takahashi https://orcid.org/0000-0002-4738-5273 (D) Professor at the Federal University of Paraná (UFPR) \\ $\mathrm{PhD}$ in Business Administration at the Federal University of São Paulo (USP) \\ adrianarwt@gmail.com}

\section{Emanuel Campigotto Sandri}

https://orcid.org/0000-0002-4539-2090 (D) $\mathrm{PhD}$ student in Administration at the Federal University of Paraná (UFPR)

Master in Business Administration at the State University of Western Paraná (UNIOESTE) emanuel.sandri@hotmail.com

\section{Ana Paula Mussi Szabo Cherobim}

https://orcid.org/0000-0001-9380-5403 (10 Professor at the Federal University of Paraná (UFPR)

$\mathrm{PhD}$ in Business Administration at the Federa University of São Paulo (USP)

cherobimanapaula@gmail.com

\section{Article Information}

Uploaded on 06 April 2020

Final version on 08 June 2020

Accepted on 10 June 2020

Published online on 29 June 2020

Interinstitutional Scientific Committee Editor-in-chief: Diego de Queiroz Machado Evaluation by the double blind review system (SEER / OJS - version 3)

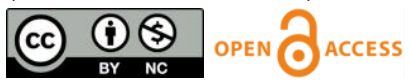

\section{ABSTRACT}

We use a meta-synthesis approach to review qualitative case studies where the relationship between value and digital transformation/industry 4.0 is explored. Our goal is to provide contributions beyond those achived on the original studies, thus providing novel insights from the study findings. The results demonstrate that value is explored on two dimensions: Business Models and value chains. However, we identify that studies tend to overlook critical points of industry 4.0 when exploring value. This meta-synthesis demonstrate that studies need to encompass a broader scenario, dealing also with co-creation of value and also considering ecosystem aspects where the organizations are inserted for the comprehension of value capture aspects. We conclude by providing future research directions based on the meta-analysis of the reviewed studies.

Keywords: digital transformation; industry 4.0; value; meta-synthesis; case studies.

\section{RESUMO}

Utilizamos a abordagem metassíntese para analisar estudos de caso qualitativos, onde a relação entre valor e transformação digital/indústria 4.0 é explorada. O objetivo é prover contribuições que vão além das encontradas nos estudos originais, assim apontando novos insights a partir dos achados dos estudos. Os resultados demonstram que o valor foi explorado em duas dimensões: modelos de negócios e cadeias de valor. Porém, identificamos que os estudos tendem a negligenciar pontos críticos da indústria 4.0 para explorar valor. Essa metassíntese demonstra que os estudos devem abordar um cenário mais amplo, lidando também com os aspectos da co-criação de valor e considerando aspectos do ecossistema onde as organizações estão inseridas para compreender aspectos da captura de valor. Nós concluímos provendo direções para pesquisas futuras com base na meta-análise dos estudos revisados.

Palavras-chave: transformação digital; indústria 4.0; valor; meta-síntese; estudos de caso.

\section{RESUMEN}

Utilizamos el enfoque de meta-síntesis para analizar estudios de caso cualitativos donde se explora la relación entre valor y transformación digital/industria 4.0. El objetivo es proporcionar contribuciones que vayan más allá de las encontradas en los estudios originales, proporcionando así nuevas ideas a partir de los resultados de los estúdios. Los resultados demuestran que el valor se exploró en dos dimensiones: modelos de negocios y cadenas de valor. Sin embargo, descubrimos que los estudios tienden a descuidar los puntos críticos de la industria 4.0 para explorar el valor. Esta meta-síntesis demuestra que los estudios deben abordar un escenario más amplio, que también trata aspectos de la cocreación de valor y considera aspectos del ecosistema donde las organizaciones se insertan para comprender aspectos de la captura de valor. Concluimos brindando instrucciones para futuras investigaciones basadas en el metanálisis de los estudios revisados.

Palabras clave: transformación digital; industria 4.0; valor; meta-síntesis; estudios de caso.

\section{How to cite this article:}

Cruzara, G., Takahashi, A. R. W., Sandri, E. C., \& Cherobim, A. P. M. S. (2020). The impact of digital transformation and industry 4.0 on the aspects of value: Evidence from a meta-synthesis. Contextus - Contemporary Journal of Economics and Management, 18(8), 92-106. https://doi.org/10.19094/contextus.2020.43717 
1 INTRODUCTION

The German Government first mentioned industry 4.0 in 2011 (Kagerman et al., 2013). It describes an organization where employees and machines interact with one another like on a social network, resulting in greater integration at the organizations (Kagerman et al., 2013).

To be characterized as an 'industry 4.0', the organization pass through a process called 'digital transformation', which is characterized as the application of digital technologies to the organizations. These technologies create what is called Cyber-Physical Space CPS (Khaitan \& McCalley 2015), which represents the interconnection between the physical and the virtual layers of an organization (Spath et al., 2013).

In this sense, digital transformation and the industry 4.0 affect a number of organizational aspects, such as: governance and regulatory frameworks (Weber, 2013; Docherty et al., 2017), value creation processes (Arnold et al., 2017; Müller et al., 2018), business models (Kagerman et al., 2013, Burmeister et al., 2016; Kiel et al., 2017), and also dynamic capabilities (Orlandi, 2016; Zeng et al., 2017; Teece, 2018a; 2018b).

Kagerman et al. (2013) also point that the CPS can be extended to outside the organization, encompassing a broader scenario that contains multiple organizations. Nevertheless, although the literature points out to different organizational aspects being affected by the digital transformation and the industry 4.0, these are encompassed by a very technical background, since this transformation was originated at the engineering and computer science streams. Due to that, most academic literature concentrates on the exploration of the technical challenges related to the digital transformation and industry 4.0 (Liao et al., 2017), while the economic and business management perspectives are still underexplored at the academy (Arnold et al., 2017).

The study of Liao et al. (2017) demonstrates that scenario, were from the 224 reviewed papers, its identified that $41 \%$ and $28 \%$ of the sample was respectively related to computer sciences and engineering streams, with the remaining $31 \%$ being shared among 13 different streams of research, including business and management.

Considering that gap on the literature, we use the meta-synthesis research design proposed by Hoon (2013), to analyze qualitative case studies that explored the relationship between the digital transformation and industry 4.0 with aspects of value at the organizations, aiming to comprehend how value is affected by industry 4.0 and digital transformation. By following Hoon (2013) protocol, we aimed to provide contributions beyond those achived on the original studies, thus providing novel insights from the study findings.

For a better understanding, this paper is structured as follows: The next section provides a literature review for the digital transformation and industry 4.0. After that, we review the literature regarding the aspects of value. We then proceed to the methodology, which contains seven subsections that represent the phases of the meta-synthesis protocol of Hoon (2013). Lastly, we provide the concluding remarks for the present study, which represents the final step of the meta-synthesis protocol, also containing future research directions.

\section{THEORETICAL FRAMEWORK}

\subsection{Digital transformation and industry $\mathbf{4 . 0}$}

The incorporation of digital technologies to the industrial activities resulted in the concept of industry 4.0 (Kagerman et al., 2013), where the utilization of digital technologies allows products, people and machines to be monitored in real-time (Kagerman et al., 2013; Xu et al., 2018). This is is achieved by the orchestrated use of technologies such as: artificial intelligence, machine learning, virtual and augmented reality, 3D printers, additive manufacturing, drones, collaborative robots, internet of things (IoT), cloud and cognitive computing, and also advanced analytics, to mention a few. The role of these technologies is to collect, transfer and make sense of a large volume of data to develop organizations that can respond to the market demand of high-quality and customized products and services (Kagerman et al., 2013; Liao et al., 2017).

One can thus see that industry 4.0 is characterized by the integration of the physical and virtual domains of an organization, performed with the use the Cyber-Physical Space (CPS). According to Xu et al. (2018), the CPS triggers a disruption at organizational activities, which occurs due to the digitalization, extraction, analysis and report activities that allows various digital technologies to create value (Kagerman et al., 2013; Kiel et al., 2017).

Considering that, industry 4.0 can be defined as an "increased digitization and automation in addition to increased communication enabled by the creation of a digital value chain" (Oesterreich \& Teuteberg 2016, p. 122).

Kagerman et al. (2013, p. 14) provides another definition, stating that industry 4.0 is:

The technical integration of the CPS into the manufacturing and logistics processes, and the use of Internet of Things and Services (IoTS) in the industrial processes. Which will have implications for value creation, business models, downstream services and the working organization as a whole.

To have the CPS implemented, the organization pass through a process called digital transformation (Spath et al., 2013), which, according to Kagerman et al. (2013), can also encompass concepts such as: smart mobility (Cassandras, 2017; Docherty et al., 2017); smart logistics (Gregor et al., 2017; Hofmann \& Rusch, 2017); smart buildings (Carr et al., 2017; Lilis \& Kayal, 2017); smart products (Porter \& Heppelmann, 2015) and smart grids (Carr et al., 2017; Park et al., 2017).

In this sense, digital transformation promotes an integration into what is called digital value chain (Kagerman et al., 2013; Oesterreich \& Teuteberg, 2016; Fatorachian \& Kazemi, 2018; Xu et al., 2018), where some studies 
demonstrate aspects of value being affected at the organizations (Arnold et al., 2017; Kiel et al., 2017; Lichtenhaler, 2017; Müller et al., 2018; Müller, 2019).

These aspects are demonstred in some studies that use case studies as the methodological approach, such as Kiel et al. (2017), where is demonstrates how organizations managed to change their business models to adapt to the digital transformation and industry 4.0. At their study, the authors demonstrating which blocks of the organizational business model were affected by the digital transformation. According to their findings, the value proposition was one of the the most affected blocks. Zeng et al. (2017) is another study that use case study approach to explore the digital transformation and industry 4.0. At their study, the authors analyze two Chinese manufacturing organizatons, demonstrating the dynamic capabilities that were developed during the three phases that the organizations passed to digitally transform themselves. The developed resulted are pointed by the authors as one item that impacted the aspects of value at the organizations.

\subsection{The organizational aspects of value}

According to Sánchez-Fernández and Iniesta-Bonilla (2007), value is one of the most ill-defined constructs in the area of management. Ito et al. (2012) point out that studies often relate value to strategic decisions of organizations. In this sense, most studies explore aspects related to the imitability of the value offered by an organization. Thus, they consider that 'value is out there', to which a connection to the idea of an organization being seen as a bundle of resources is established (Peteraf, 1993; Rumelt, 1984).

Value is also often related to competitive advantage, and although some studies point to a difference between types of value (Bowman \& Ambrosini, 2000; Pitelis, 2009), most studies aim to explore questions related to value creation to explain how competitive advantage can be achieved (Brito \& Brito, 2012).

In a general sense, the idea of what is value dates back to the studies of Marx (1867/1990), where differentiation between use-value and exchange-value, apart from the well know labor-value is made. According to that perspective, use-value is related to the fulfillment of a personal need, while the exchange-value is an economic value that will be defined by the social context (Ito et al., 2012). In other words, the exchange-value is more related to an objective dimension (encompassing financial aspects), while the use-value is more related to a subjective dimension (encompassing the perception of value by someone).In this sense, it's assumed that different people will have different sense and needs, which combined with an information asymmetry at the market (Mishra et al. 1998) creates different perceptions of value, ultimately allowing trades and exchanges to be made.

The subjective aspects of value also lead to a discussion regarding value creation and value capture, where Grönroos (2008) states that, in a general level, value creation entails a process related to increasing the customer wellbeing (the idea of 'make a user feel better in some aspect'). Nevertheless, the same author points in another study (Grönroos \& Voima, 2013) that value creation is not explicitly defined, often being addressed by the literature as something entangled with the co-creation of value, which is the idea of simultaneous value creation between the service provider and its customer.

Despite that, what is common for both the value creation and co-creation is that both aspects are perceived by the customer on what is called value-in-use (Helkkula et al., 2012). In other words, in the first case (value creation), there's a value being delivered by the organization, which is later perceived by its customer through the value-in-use. In the second case (value co-creation) there's a co-creation of value between the organization and its customer.

Furthermore, both the value creation and co-creation encompasses not just the delivery of value, but also other dimensions that are related to the customer that an organization has (such as their relationship). In this sense, it includes the entrepreneurial activities (Bowman \& Ambrosini, 2000); the resources of the organization (Barney, 1991), the specific activities performed by the organization (Porter, 1996), and the capabilities that an organization has (Teece, 2014).

Considering that, value is here perceived as the combination of the value that the customer sees from a service or product provided by the organization (value delivery), combined with the proper identification of customers and the relationship that the organization maintain with its customers (Baden-Fuller \& Haefliger, 2013; Grönroos \& Voima, 2013). This leads the organization to capture value, which tends to be addressed by the literature in terms of an economic dimension (especially at business model literature) (Lecocq et al., 2006; Osterwalder \& Pigneur, 2010; Baden-Fuller \& Haefliger, 2013; Teece \& Linden, 2017). Thus, we consider that the value is cocreated between the user and the organization, since it encompasses the delivery of something by the organization and also how the customer perceive what was delivered (Grönroos \& Voima, 2013), which is aligned with industry 4.0 literature, such as Kagerman et al. (2013), Oesterreich and Teuteberg (2016), Fatorachian and Kazemi (2018), Müller et al. (2018) and Xu et al. (2018).

\section{METHODOLOGY}

To explore how the digital transformation and industry 4.0 affect the aspects of value at the organizations, we used the meta-synthesis protocol proposed by Hoon (2013). This method is defined as "an exploratory, inductive research design to synthesize primary qualitative case studies to make contributions beyond those achieved in the original studies" (Hoon, 2013, p. 523).

The meta-synthesis proposed by Hoon (2013) is composed of eight steps, summarized in Table 1. We followed each of those steps and the details are provided at the next eight subsections of the present study. 
Table 1

Meta-synthesis protocol

Stages of the metasynthesis

Analytical goal

Strategy/analytical procedure used

The outcome to generate a theoretical contribution

Framing the research question for the meta-synthesis, where we aim

1. Framing the research question to gain greater familiarity with the field, thus addressing the least discussions and upon that identify the theoretical gap in the literature.

\section{Locating relevant} research

Identification of relevant publications in the area of industry 4.0/digital transformation that explored the concept of value.
Search and reading academic

publications about the field of Identification of the theoretical gap industry 4.0/digital transformation to be addressed at the metagiving special attention to future synthesis

research directions.

Two searches, a first one using the keywords "digital transformation" AND "case stud"", and a second one using the keywords "industry 4.0" AND "case stud*". Searches were performed at the title, abstracts or keywords with no time frame restriction at the databases Web of Science, Scopus and EBSCO (Business Source Ultimate).

Inclusion of papers that were Four inclusion criteria that were A final sample containing 5 studies consistent with the scope of the developed to select the most to be analyzed at the present present research. relevant studies to be analyzed.

A careful reading of the selected Development of an excel file Organization of the coding aspects papers. Coding the characteristics containing the coded data of each and construction of a broad and insights of each study. paper. overview of each paper.

Identification of the main themes, the level of analysis displayed at the studies and the information on how the case explored the aspects of value. aspects of value.

6. Synthesizing on an across-study level

Analysis of the cases altogether with the development of the metacausal network.

Meta-causal network and crosscase data table built upon the causal networks created at the previous phase.

Identification of the relationship

7. Building theory between the aspects of value and from meta-synthesis 4.0.

Establishing the link between the results with the reviewed literature.

\section{Discussing}

Discussion of the meta-synthesis results and its limitations.

\section{Discuss}

validity.
Identification of the logical patterns from each case and their relationship.

Identification and understanding of how value is affected by the digital transformation and industry 4.0.

Legitimize the validity and reliability rigor, reliability, and of the procedures and activities that were performed at the present study.

Source: Development by the authors.

\subsection{Framing the research question}

To address the first phase of Hoon (2013) methodology, the literature related to the industry 4.0 and digital transformation was reviewed, with special emphasis being given to the future research directions and theoretical gaps pointed by the studies. Since one of the researchers was already working with this subject for the past two years, this facilitated the identification of the research question, as several studies where already reviewed by this researcher.

That approach is aligned with Hoon (2013) protocol, where it's stated that a clear comprehension of the phenomenon being studied is important to frame a viable and valuable research question for the meta-synthesis. Considering the reviewed literature, the following research question was framed for the meta-synthesis: How the digital transformation and industry 4.0 affect the aspects of value at the organizations?

\subsection{Locating relevant research}

As previously mentioned, industry 4.0 and digital transformation are two concepts related to one another, where studies aim to describe the scenario through which the organization implement and integrate digital technologies.

In this sense, we searched for high-quality qualitative case studies addressing that scenario. To be considered a high-quality qualitative case study, the study should present a consistent construction, thus proving on the overall a good description of the theoretical framing and research context, a good methodology section encompassing data collection and data analysis and also a good discussion about the findings of the study. To this end, the items described at Table 3, located at section 3.3 (inclusion criteria); and the codes summarized at Table 6 , located at section 3.4 
(extracting and coding) assisted us to validate the studies and organize the collected information.

We searched for studies at the databases Web of Science, Scopus, and EBSCO (Business Source Ultimate). The first two databases were selected because as pointed by Vieira and Gomes (2009), they display the citation impact of the documents in the core to be higher. Furthermore, we decided to use both databases because the authors point that while about $2 / 3$ of the documents referenced in any of the two databases may be found in both databases, another $1 / 3$ of the studies of their sample were only referenced in one database or the other. Thus, to include these $1 / 3$ studies we decided to select both databases. Furthermore, the database EBSCO (Business Source Ultimate) was included since the researchers had access to all full texts within this database, which could enhance the number of potential studies.

To search these three databases, two keywords "industry 4.0" and "digital transformation" were combined with a third one named "case stud" (encompassing the variations study and studies). We conducted the first search was using the string "digital transformation" AND "case stud" $^{*}$ at the three databases. Later, we performed the search using the string "industry 4.0" AND "case stud"". Both searches were performed during the second week of June of 2019.

The first database that we searched was the Web of Science, followed by Scopus and later by EBSCO. In this sense, we used the first search string on the first database, which had the identified studies extracted and added to an excel file. After that, we used the first search string on the second database, which also had its results extracted to another excel database, with duplicated entries being

Table 2

Strings used and number of papers identified/selected

$\begin{array}{cc}\text { String used } & \text { Initial results / Results } \\ \text { after restrictions (WEB } \\ \text { OF SCIENCE) }\end{array}$

\begin{abstract}
"digital transformation" AND "case stud*"
\end{abstract}
$75 / 18$

"industry 4.0" AND "case stud""

$267 / 15$ removed. After that, we performed the same procedure on the third database. Later, the same process was performed for the second search string, where we also double-checked the extracted results of each database against the ones obtained from the first string. By using that approach, we ensured that no duplicated study was added to our sample. To limit the number of results, we performed the searches with the following restrictions:

- Web of Science: Only articles of the Areas of Business and Management - due to the high number of studies that were identified, especially within areas related to computer science and engineering.

- Scopus: Only articles of the area Business, Management, and Accounting that had their full text in English, Spanish or Portuguese - again due to the high number of studies that were identified on aread of studies from engineering and computer science and also also restricted the full text to languages that were understandable by the researchers.

- EBSCO: Only academic journals with full text available in English, Spanish or Portuguese - since EBSCO did not allowed the restriction to be made by 'articles', we restricted the results by considering only studies published in academic journals (peer reviewed ones) that had their full text in languages understandable by the researchers.

Table 2 summarizes the number of papers identified at each databaseconsidering the restricitions and also the removal of duplicated entries. A sample of 76 papers was selected to be analyzed at the next phase (36 with the first search string, and 40 with the second search string).

Source: Development by the authors.

\subsection{Inclusion criteria}

We read the titles, keywords and abstracts of each of these 76 studies, aiming to identify if the paper met the inclusion criteria that are presented in Table 3 . The inclusion critera was adapted from Hoon (2013) study in order to encompass the context of digital transformation, industry 4.0 and value. Thus, the inclusion criteria is the same used at her study, but the rationales were adapted to the context here explored.

A total of 76 studies were fully read to verify if they meet the inclusion criteria described in Table 3. After verifying these 76 studies, a final sample composed of five studies emerged. Altought the final sample of studies might
Initial results / Results Initial results / Results after restrictions / new after restrictions / new results - duplicates results - duplicates removed (SCOPUS) removed (EBSCO)

Number of selected studies

$186 / 26 / 13$

$54 / 14 / 5$

36

$450 / 29 / 22$

49 / 7 / 3

40 be considered small, Hoon (2013) point out that metasynthesis aims to contribute beyond those achieved in the original studies, relying on the meta-analysis of studies. Thus, a small number of cases is analyzed considering the 8 steps of the meta-synthesis protocol, which are demonstrated at Table 1.

At the study of Hoon (2013), for example, the number of analyzed papers was 9 . However, the research topic that she used to search for case studies was one already well developed at the academic field: dynamic capabilities. Since the topic that this study is exploring is relatively new, it was expected that the number of cases contained within the final sample could be smaller. 
Table 3

Inclusion criteria

Inclusion criteria

Rationales

Number of excluded papers

1. Scope of the research

Study address the industry 4.0 / digital transformation and the aspects of value, thus being related to the research question proposed and effectively exploring and developing these items along the research

The study uses qualitative case studies to explore the research scenario. This criterion

2. Qualitative case studies aims to exclude case studies mentioned as illustrative as well as studies that did not use case studies as its main methodological approach

The study uses in-depth case studies. This criterion aims to exclude studies that used

3. In-depth case studies a large sample of case studies ( $n=20$ or more), thus relying on a small number of data sources for each case, which does not characterize them as in-depth case studies.

Paper presents a consistent quality along with its construction, thus providing

4. Quality Check reliability, confiability and proving that the research was properly designed and conducted

no further papers were excluded

5 studies

Final Sample

Table 4 summarizes the selected studies with their

The complete dataset was uploaded to the Mendeley

Data, Dataset name: "Data for: The impact of digital transformation and industry 4.0 on the aspects of value: Evidence from a meta-synthesis"; file name "Reviewed_studies.xlsx".

\section{Table 4}

Studies selected to be analyzed

\begin{tabular}{lll}
\hline $\begin{array}{l}\text { Authors/ Year } \\
\begin{array}{l}\text { Jerman et al. } \\
(2019)\end{array}\end{array}$ & Journal & Title \\
$\begin{array}{l}\text { Pesce et al. } \\
(2019)\end{array}$ & Current Issues in Tourism & $\begin{array}{l}\text { The Influence of Critical Factors on Business Model at a Smart } \\
\text { Factory: A Case Study }\end{array}$ \\
$\begin{array}{l}\text { Arribas and } \\
\text { Alfaro (2017) }\end{array}$ & Journal of Fashion Market and Management & $\begin{array}{l}\text { When culture meets digital platforms: value creation and stakeholder's } \\
\text { alignment in big data use }\end{array}$ \\
Shin (2017) & $\begin{array}{l}\text { Asia Pacific Journal of Innovation and } \\
\text { Entrepreneurship }\end{array}$ & $\begin{array}{l}\text { An exploratory study of innovation strategies of the internet of things } \\
\text { SMEs in South Korea }\end{array}$ \\
\hline Gerlitz (2016) & $\begin{array}{l}\text { The international journal of entrepreneurship } \\
\text { and sustainability issues }\end{array}$ & $\begin{array}{l}\text { Design Management as a domain of smart and sustainable enterprise: } \\
\text { business modeling for innovation and smart growth in industry 4.0 }\end{array}$ \\
\hline
\end{tabular}

Source: developed by the authors. respective journal and title, while Table 5 contain details of the reviewed studies.

\section{Table 5}

Details of studies selected to be analyzed

\begin{tabular}{|c|c|c|c|c|}
\hline Authors/ Year & $\begin{array}{l}\text { Numer of } \\
\text { cases }\end{array}$ & Country & Sector/Industry & Level of Analysis \\
\hline $\begin{array}{l}\text { Jerman et al. } \\
(2019)\end{array}$ & 1 & Slovenia & $\begin{array}{l}\text { Manufacturing / } \\
\text { Automotive }\end{array}$ & Organizational / Business model \\
\hline $\begin{array}{l}\text { Pesce et al. } \\
\text { (2019) }\end{array}$ & 2 & $\begin{array}{l}\text { Organizations acting on } \\
\text { various European countries }\end{array}$ & $\begin{array}{l}\text { Tourism / Cultural } \\
\text { heritage }\end{array}$ & $\begin{array}{l}\text { Inter-organizational / relationship between the } \\
\text { organizations and their stakeholders }\end{array}$ \\
\hline $\begin{array}{l}\text { Arribas and } \\
\text { Alfaro (2017) }\end{array}$ & 1 & France & $\begin{array}{l}\text { Manufacturing / } \\
\text { fashion industry }\end{array}$ & $\begin{array}{l}\text { Organizational level (specific project developed by } \\
\text { the organization) / employees as the unity of analysis }\end{array}$ \\
\hline Shin (2017) & 1 & South Korea & $\begin{array}{l}\text { Electro-electronic / } \\
\text { IT connection } \\
\text { company (focus on } \\
\text { mobile } \\
\text { technologies) }\end{array}$ & $\begin{array}{l}\text { Inter-organizational / development of partnerships / } \\
\text { organizations value chains }\end{array}$ \\
\hline Gerlitz (2016) & 1 & Germany & $\begin{array}{l}\text { Business } \\
\text { consulting / } \\
\text { Planning and } \\
\text { Implementation }\end{array}$ & $\begin{array}{l}\text { Organizational level / employees as the unity of } \\
\text { analysis }\end{array}$ \\
\hline
\end{tabular}

Source: developed by the authors. 
Cruzara, Takahashi, Sandri \& Cherobim - The impact of digital transformation and industry 4.0 on the aspects of value

\subsection{Extracting and coding}

We analyzed the selected studies following the the studies. coding procedure from Hoon (2013) protocol. In this sense,

\section{Table 6}

Coding form

\section{CASE STUDY $X$}

\begin{tabular}{lll}
\hline Group & Item No. Code & Code \\
Details
\end{tabular}

\begin{tabular}{|c|c|c|}
\hline \multirow{4}{*}{ General details of the study } & 1 & Author(s) \\
\hline & 2 & Title \\
\hline & 3 & Journal \\
\hline & 4 & Published year \\
\hline \multirow{3}{*}{$\begin{array}{l}\text { What are the authors trying to } \\
\text { achieve (Focus of the research) }\end{array}$} & 5 & The general aim of the research \\
\hline & 6 & Study objective \\
\hline & 7 & Research question(s) \\
\hline \multirow{3}{*}{ Theoretical framing } & 8 & $\begin{array}{l}\text { What is the concept of digital transformation/industry } 4.0 \text { considered at the } \\
\text { study? }\end{array}$ \\
\hline & 9 & What is the concept of value considered in the study? \\
\hline & 10 & $\begin{array}{l}\text { How is the relationship between digital transformation/industry } 4.0 \text { and value } \\
\text { treated? }\end{array}$ \\
\hline \multirow{3}{*}{$\begin{array}{l}\text { Setting / context in which study is } \\
\text { conducted }\end{array}$} & 11 & Country \\
\hline & 12 & Sector / Industry \\
\hline & 13 & Research context \\
\hline \multirow{4}{*}{ Methodology } & 14 & Type of case study \\
\hline & 15 & Number of cases analyzed \\
\hline & 16 & Level/unity of analysis \\
\hline & 17 & Sampling design \\
\hline \multirow{4}{*}{$\begin{array}{l}\text { Data collection techniques data } \\
\text { and sources }\end{array}$} & 18 & Time and sequence of the data collection \\
\hline & 19 & Techniques used by the researcher(s) \\
\hline & 20 & Data Sources \\
\hline & 21 & Amount of data collected \\
\hline Data analysis & 22 & Data analysis approach \\
\hline \multirow{5}{*}{ Key findings and insights } & 23 & $\begin{array}{l}\text { Key findings as summarized by the researcher(s) in abstract/ introduction } \\
\text { and conclusion section }\end{array}$ \\
\hline & 24 & Events, factors or patterns pointed by the researcher \\
\hline & 25 & Effects of the digital transformation/industry 4.0 in the concept of value \\
\hline & 26 & Environmental conditions \\
\hline & 27 & $\begin{array}{l}\text { Visualization of the conceptual model or framework provided by the } \\
\text { researcher(s) }\end{array}$ \\
\hline \multirow{5}{*}{ Discussion } & 28 & Discussion of key findings \\
\hline & 29 & Contributions to the field of digital transformation/industry 4.0 \\
\hline & 30 & Contributions to the field of value \\
\hline & 31 & Limitations pointed by the original researcher(s) \\
\hline & 32 & Limitations of the study (e.g. Methodology) \\
\hline \multirow{4}{*}{ Overall assessments } & 33 & How relevant is this study to the underlying question? \\
\hline & 34 & How reliable/convincing is the study? \\
\hline & 35 & Missing information / logical inconsistencies? \\
\hline & 36 & Further comments \\
\hline
\end{tabular}

Source: Hoon (2013). 
The dataset containing the coded data for the five reviewed studies was uploaded to the Mendeley Data, Dataset name: "Data for: The impact of digital transformation and industry 4.0 on the aspects of value: Evidence from a meta-synthesis"; file name "Coding_form.xlsx".

\subsection{Analyzing a case-specific level}

Following the procedures described by Hoon (2013), we first analyzed the studies individually. To perform the analysis, we used the causal network technique. The causal networks were developed upon the coding of each study, which was performed based on the coding form of last section.

The networks were developed following Miles and Huberman (1994) sequence of variables approach, with each case being explored considering the variables that logically influence one another, the variables that would appear together and the variables that would create a process sequence. To this end, the causal networks contemplates the logical aspects of how industry 4.0 and digital transformation affect the aspects of value at the analyzed studies.

One causal network was developed for each of the five reviewed studies, and they were uploaded to the Mendeley Data, Dataset name: "Data for: The impact of digital transformation and industry 4.0 on the aspects of value: Evidence from a meta-synthesis"; file name "causal_networks.xlsx".

By analyzing these causal networks, one will be able to identify the logical process of influence developed by the studies when exploring value and digital transformation / industry 4.0. At the study of Pesce et al. (2019), for example, it can be noted that an aligment of stakeholder interests combined with integration and portability of digital technologies would lead to value creation, which results in improved customer experience and greater co-criation of value.

All categories existing at the causal networks were extracted from the studies. Thus, altought we were aiming to explore how digital transformation and industry 4.0 affected the aspects of value, the categories present at the causal networks were identified upon the coding procedure described at section 3.4.

From the causal networks, it was identified that two studies explored the aspects of value relying on the concept of business models and two other explored the aspects of value relying on the concept of value chain, while one study did not use these concepts and explored value by itself, only mentioning that it can be related to the business models and the value chains of organizations.

Furthermore, the causal networks demonstrate that co-creation of value was only mentioned at the study of (Pesce et al., 2019). Other studies, such as Jerman et al. (2019), Arribas and Alfaro (2017) and Gerlitz (2016), cite improved customer experience as an outcome of value creation. Improved customer experience is pointed at the industry 4.0 as being an outcome created due the cocreation of value (Kagerman et al., 2013; Kiel et al., 2017; Müller et al., 2018).

Apart from that, only the study of Grelitz (2016) discussed value capture considering environmental and social spheres, which demonstrates that value capture is still encompassed with more emphasis at the economic dimension, even thou social and environmental are mentioned as being related to industry 4.0 (Kagerman et al., 2013).

The causal networks developed in this section served as the base for the development of the meta-causal network, eplored next.

\section{RESULTS}

\subsection{Synthesis on a cross-study level}

The meta-causal network displayed at Figure 1 was constructed considering the causal networks developed on the last phase. By following Hoon (2013) guidelines, we analyzed similarities and differences between the causal networks. The coding form of each study was also used to have the meta-causal networ developed. Thus, this metacausal network represents how all studies could have their findings connected to one another, which serve as the base for the discussion present at next secion of the metasynthesis.

The meta-causal network is displayed at Figure 1, where we can see that value was mainly explored with two main approaches: 1 (business models); and 2 (value chains). In this sense, when 3 (digital transformation technologies / industry 4.0) are added to the scenario, it results in 4 (greater challenges to create and capture value). Upon that, we identified that organizations could use the aspects of 5 (aspects pointed by the studies that assist the creation and capture of value) to overcome the challenges and thus achieve 6 (increased value creation and capture (on business models and value chains)), which ultimately assist the organization to achieve 7 (outcomes of a greater value creation and capture).

In this sense, the meta-causal network not just represents the findings of each study, but also how their findings can be related to ane another, encompassing a broader scenario. Thus, the categories that appear at the meta-causal network are inherited from the causal networks developed during the previous phase.

Furthermore, we analyzed the studies considering the results of Table 7 , which was also developed considering the causal networks created at the previous section, as well as the coding form created for each study. In this sense, the categories of Table 7 aimed to demonstrate key findings of each study, such as if the analyzed organizations generate more value, the main perceived characteristic of industry 4.0 / digital transformation and the the effect that industry 4.0 / digital transformation had on the aspects of value. Considering that, while Figure 1 represents the relationship between the findings of the studies, Table 7 summarizes 
Cruzara, Takahashi, Sandri \& Cherobim - The impact of digital transformation and industry 4.0 on the aspects of value their individual characteristics, allowing them to compliment the column "Main challenge generated by digital one another to have the next phase of the analysis performed.

Thus, by looking at Figure 1 we can see, for example, the box named " 4 . Greater challenges to create and capture value", which can be complimented with the information of transformation/industry 4.0", located at Table 7 . In this sense, Figure 1 and Table 7 should be analyzed as complementary to one another, encompassing the connections between the study findings, and the individual characteristics of each study.

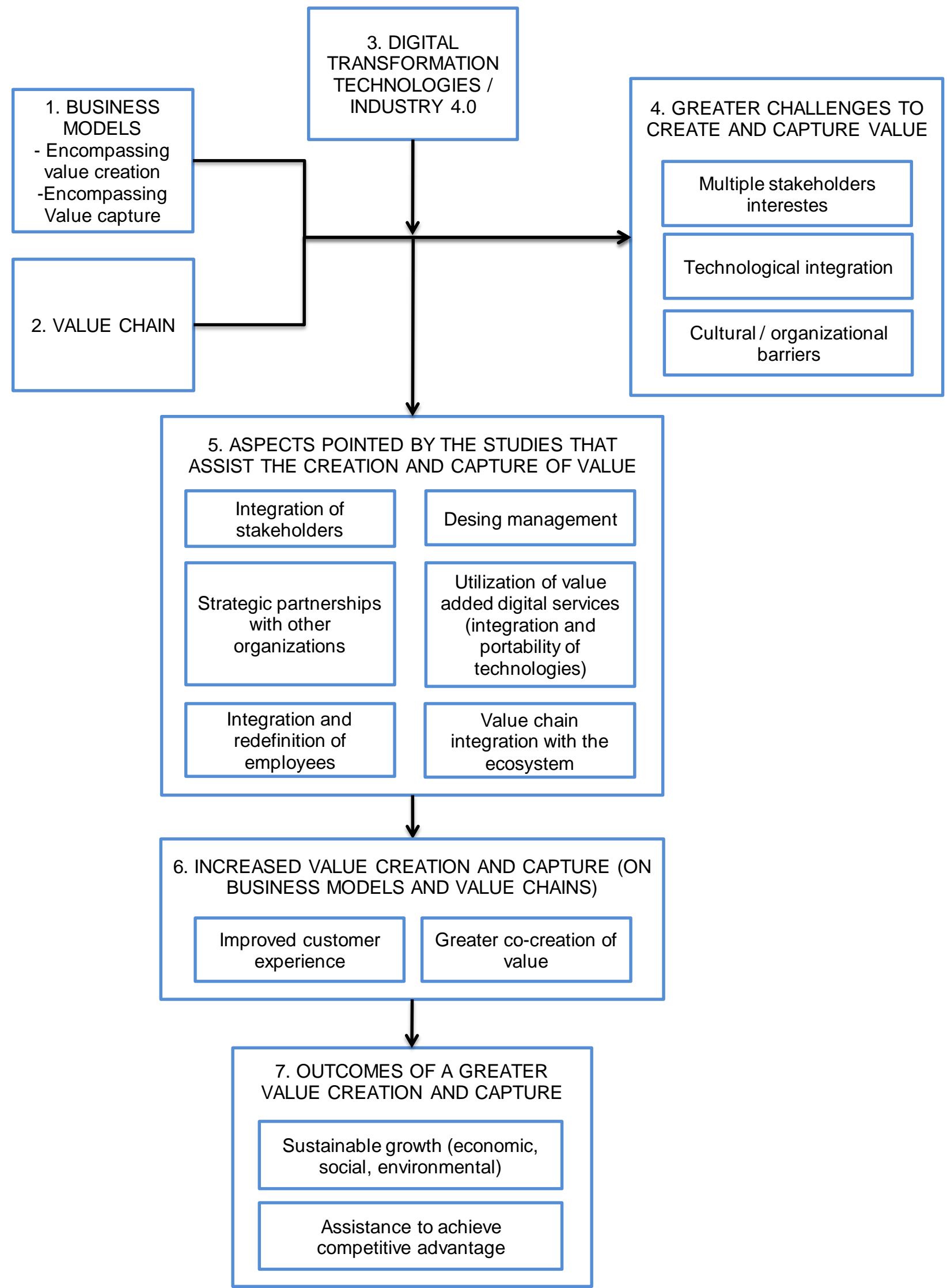

Figure 1. Meta-causal network of the analyzed studies Source: developed by the authors. 
Cross case analysis

\begin{tabular}{|c|c|c|c|c|c|c|}
\hline $\begin{array}{l}\text { Case } \\
\text { number/ } \\
\text { author }\end{array}$ & $\begin{array}{c}\text { Approach } \\
\text { used to } \\
\text { explore Value }\end{array}$ & $\begin{array}{l}\text { Mainly perceived } \\
\text { characteristic of digital } \\
\text { transformation / } \\
\text { industry } 4.0\end{array}$ & $\begin{array}{c}\text { Effects of the industry } 4.0 \\
\text { to the concept of value }\end{array}$ & $\begin{array}{l}\text { Main challenge } \\
\text { generated by digital } \\
\text { transformation / } \\
\text { industry } 4.0\end{array}$ & $\begin{array}{l}\text { Positive } \\
\text { outcomes of } \\
\text { digital } \\
\text { transformation } \\
\text { / industry } 4.0\end{array}$ & $\begin{array}{c}\text { The analyzed } \\
\text { organization } \\
\text { generated } \\
\text { more value }\end{array}$ \\
\hline $\begin{array}{c}1 . \\
\text { Jerman } \\
\text { et al. } \\
(2019)\end{array}$ & $\begin{array}{l}\text { Business } \\
\text { Models }\end{array}$ & $\begin{array}{l}\text { Integration of } \\
\text { technologies that } \\
\text { results in the CPS }\end{array}$ & $\begin{array}{l}\text { Positive / Negative - } \\
\text { depending on if the } \\
\text { organization can change } \\
\text { its business model } \\
\text { accordingly }\end{array}$ & $\begin{array}{l}\text { Organizational } \\
\text { barriers that } \\
\text { prevent business } \\
\text { model change }\end{array}$ & $\begin{array}{l}\text { Only mentions } \\
\text { greater value } \\
\text { creation and } \\
\quad \text { capture }\end{array}$ & Yes \\
\hline $\begin{array}{c}2 . \\
\text { Pesce } \\
\text { et al. } \\
(2019)\end{array}$ & $\begin{array}{l}\text { Value by itself, } \\
\text { mentioning } \\
\text { that it can be } \\
\text { related to the } \\
\text { business } \\
\text { models and } \\
\text { the value } \\
\text { chains }\end{array}$ & $\begin{array}{l}\text { Utilization of } \\
\text { technologies that } \\
\text { result in a large } \\
\text { number of } \\
\text { stakeholders involved }\end{array}$ & $\begin{array}{l}\text { Positive / Negative - Most } \\
\text { likely to be positive if the } \\
\text { organization manage to } \\
\text { integrate the interests of } \\
\text { all the involved } \\
\text { stakeholders }\end{array}$ & $\begin{array}{l}\text { A large number of } \\
\text { stakeholders with } \\
\text { different interests } \\
\text { that need to be } \\
\text { aligned }\end{array}$ & $\begin{array}{l}\text { Improved } \\
\text { customer } \\
\text { experience } \\
\text { and greater } \\
\text { co-creation of } \\
\text { value }\end{array}$ & $\begin{array}{c}\text { Yes (for both } \\
\text { cases, with } \\
\text { second case } \\
\text { (Google Arts } \\
\text { \& Culture) } \\
\text { generating } \\
\text { more value } \\
\text { than the first } \\
\text { one }\end{array}$ \\
\hline $\begin{array}{l}3 . \\
\text { Arribas } \\
\text { and } \\
\text { Alfaro } \\
(2017)\end{array}$ & Value Chain & $\begin{array}{c}\text { Integration of } \\
\text { technologies that } \\
\text { affect manufacturing } \\
\text { processes of } \\
\text { organizations }\end{array}$ & $\begin{array}{l}\text { Positive / Negative. } \\
\text { Assumed that digital } \\
\text { transformation acts } \\
\text { positively upon the value } \\
\text { chain of organizations, as } \\
\text { long as the organization } \\
\text { overcome cultural and } \\
\text { organizational barriers }\end{array}$ & $\begin{array}{l}\text { Training and } \\
\text { cultural barriers }\end{array}$ & $\begin{array}{l}\text { Improved } \\
\text { customer } \\
\text { experience }\end{array}$ & Yes \\
\hline $\begin{array}{c}4 . \\
\text { Shin } \\
(2017)\end{array}$ & Value Chain & $\begin{array}{l}\text { Application of } \\
\text { technologies that } \\
\text { result in an in-depth } \\
\text { connection between } \\
\text { organizational } \\
\text { resources }\end{array}$ & $\begin{array}{l}\text { Positive / Negative. Most } \\
\text { likely to be positive if the } \\
\text { organization use } \\
\text { partnerships (ecosystem } \\
\text { and open innovation) and } \\
\text { upon that manage to } \\
\text { integrate its value chains } \\
\text { with the other } \\
\text { organizations }\end{array}$ & $\begin{array}{c}\text { Development of } \\
\text { strategic } \\
\text { partnerships }\end{array}$ & $\begin{array}{l}\text { Only mention } \\
\text { greater value } \\
\text { creation }\end{array}$ & Yes \\
\hline $\begin{array}{c}5 . \\
\text { Gerlitz } \\
(2016)\end{array}$ & $\begin{array}{l}\text { Business } \\
\text { Models }\end{array}$ & $\begin{array}{l}\text { Utilization of } \\
\text { technologies that alter } \\
\text { the value chain } \\
\text { relationships }\end{array}$ & $\begin{array}{l}\text { Positive / Negative - Most } \\
\text { likely to be positive if the } \\
\text { organization integrate its } \\
\text { value chain and thus } \\
\text { manage to realign its } \\
\text { business model to } \\
\text { generate value }\end{array}$ & $\begin{array}{c}\text { Integration of } \\
\text { classic value } \\
\text { generation } \\
\text { strategies with } \\
\text { digital value-added } \\
\text { services provided } \\
\text { by } \\
\text { digital technologies }\end{array}$ & $\begin{array}{l}\text { Improved } \\
\text { customer } \\
\text { experience, } \\
\text { sustainable } \\
\text { growth, and } \\
\text { assistance to } \\
\text { achieve } \\
\text { competitive } \\
\text { advantage }\end{array}$ & Yes \\
\hline
\end{tabular}

Source: developed by the authors.

\subsection{Building theory from meta-synthesis}

As pointed out by Hoon (2013), meta-synthesis allows the advancement of theory by either refining or extending existing theory or by generating theory. Considering that, the discussion present in this section aims to develop contributions that go beyond the ones identified on the original studies. To this end, Figure 1 and Table 7 serve as the base for the analysis.

First, its important to state that the initial literature related to digital transformation and industry 4.0 addressed it as something that always creates positive impacts on the organizations (Kagerman et al., 2013). The studies that we analyzed demonstrate a different scenario, stating that, positive effects can only be achieved if the organization manages to overcome the challenges that digital technology creates. Figure 1 and Table 7 demonstrate that organizations need to deal with multiple stakeholders' interests, technical challenges related to technology integration and also cultural and organizational barriers, only being able to achieve positive outsomes if these items are properly addressed.

We identified that the reviewed studies and also other industry 4.0 literature such as Kiel et al. (2017) and Müller et al. (2018) explore value by either encompassing business models or value chains. However, the meta-causal network developed demonstrated that industry 4.0 and digital transformation should be explored considering both approaches, as they interrelate to on another and both directly affect the outcome of industry 4.0 at the organizations. Gerlitz (2016), for example, uses the business model as the baseline to explore value at the digital transformation. However, they identify that the 
outcome of would be either positive or negative, depending if the organization integrates its value chain, which thus lead to the business model realignment.

Considering that, a first finding is that value chain needs to be explored along with the business models, in order to understand their relationship and demonstrate how value can be created and captured at industry 4.0 context. This approach is interesting because industry 4.0 is mentioned as something that promotes a vertical and horizontal integration to the value chain (Kagerman et al., 2013). This is discussed under the concept of digital value chain, discussed at the study of Oesterreich and Teuteberg (2016). Thus, an approach dealing with business model would benefit from this vertical and horizontal integration related to value chains, as the business model could be better aligned along the value chains of organization, as demonstrated by Gerlitz (2016).

Furthermore, apart from one study Pesce et al. (2019), no other study mentioned that a co-creation of value would be an outcome of the digital transformation / industry 4.0. This go against other literature such as Kagerman et al. (2013), Kiel et al. (2017), Lichtenhaler (2017) and Müller et al. (2018), where co-creation of value is identified as an important domain for the digital tranfsoramtion. By looking at Figure 1 and Table 7, and also at the causal networks developed at section 4.1 , we identify that many items that are considered at industry 4.0 literature as being related to co-creation of value (Kagerman et al., 2013; Kiel et al., 2017; Müller et al., 2018), are approached on the reviewed studies of this meta-synthesis as being of value creation itens. In other words, the reviewe studies follow a line of research stating that the creation of value relies solely or, on the most part, within the organization.

This draws back on the discussion between value creation and co-creation (Grönroos \& Voima, 2013). As we mentioned, industry 4.0 literature speak of co-creation of value as a very important item for digital transformation (Kagerman et al., 2013; Arnold et al., 2017). The studies we reviewed, according to Figure 1 and Table 7, point out to items that should suppor that idea, demonstrating items that are relate to co-creation of value, such as alignment of business model (Jerman et al., 2019), overcome of cultural and organizational barriers (Arribas \& Alfaro, 2017), development of partnerships (Shin, 2017), and integration of value chain (Gerlitz, 2016). Furthermore, improved customer experience, something very well discussed at industry 4.0 literature (Kagerman et al., 2013; Kiel et al., 2017) as well as within the value co-creation literature (Grönroos \& Voima, 2013) is mentioned at the studies of Pesce et al. (2019), Arribas and Alfaro (2017) and also Gerlitz (2016). However, only the study of Pesce et al. (2019) speficially mentioned co-creation of value. Thus, we state that studies would benefit from a review of the value co-creation literature, since with the used approach, they draw the attention of value creation solely for the organization, relying mainly on its internal components. Altought itens such as partnerships are mentioned, they are explored considering the creation of value just for the analyzed organization, thus being agains the idea of shared value creation (Grönroos \& Voima, 2013; Teece \& Linden, 2017 ) that is very often mentioned at industry 4.0 literature (Kagerman et al., 2013).

Furthermore, since technology integration creates a closer connection between the organizations, their value chains become more intertwined due to multiple stakeholders that will influence the value creation process. The study of Pesce et al. (2019) specifically discussed the involvement that stakeholders had to the value aspects of digital transformation. At their study, stakeholders ranged from customers, government organizations from different countries, plarform owners and platform users, as well as technology providers. The complex scenario provided by their study reflects upon challenges related to governance and regulatory frameworks that were already addressed by other studies such as Weber (2013) and Docherty et al. (2017), but that are not yet explored at studies dealing with value aspects of digital transformation. From Figure 1 and Table 7, we can see that the aspects of value could be either positive or negative affected by industry 4.0 , and based on the findings of this meta-synthesis and considering results pointed out by Weber (2013) and Docherty et al. (2017), we suggest that these outcomes are directly related to regulatory and governance aspects that are yet to be taken into consideration on studies addressing value aspects.

Apart from that, we also identify that only the study of (Gerliz, 2016) mentioned aspects related to sustainable value creation, thus encompassing environmental and social dimensions, apart from the economic one. As demonstrated at the meta-causal network (Figure 1), social and environmental value creation could also be explored at digital transformation and industry 4.0 studies, something that was very underexplored so far, even thou one of the most cited studies at the academy (Kagerman et al., 2013) points to a directly connection between them.

And last but not least, we identified that all reviewed studies stress the importance of organizational ecosystem, partnerships and open innovation approaches when it comes to value creation and capture at the digital transformation/industry 4.0. And although Kagerman et al. (2013) and Liao et al. (2017) pointed out to the creation of an integrated value chain, and that Kiel et al. (2017) and Müller et al. (2018) stated that digital transformation would change the way value is created and captured at the organizations, the reviewed studies demonstrates that value continue to be explored under an approach that does not fully encompasses the complexity of industry 4.0 and digital transformation. Industry 4.0 literature states that there is a shift from the focus on internal resources to external ones, demanding organizations to focus even more on the ecosystem and inter-organizational resources (Kagerman et al., 2013; Kiel et al., 2017; Liao et al., 2017). In this sense, the literature demonstrates that value will be even more cocreated by the whole ecosystem where the organization is inserted (Müller et al., 2018). 
This complexity demandas studies to properly address the aspects of creation of value, and more importantly, the aspects of co-creation of value (Grönroos \& Voima, 2013). On the scenario where scenario of multiple organizations competing to capture the value that was created, the result could be the destruction of the competitive advantage of the ecosystem. Thus, we sustain that studies should not just look to the positive outsomes of digital transformation, but to the negative aspects as well, something that the reviewed studies give a first step for, assuming that the value could be positive or negative, but not yet demonstrating the negative of industry 4.0 and digital transformation, nor encompassing the broader scenario that needs to be taken in consideration to understand value aspects at the ecosystem level.

\section{CONCLUSIONS}

Following Hoon (2013) protocol, we will first address in this final section the general limitations of this metasynthesis. As stated by Hoon (2013), meta-synthesis is an approach that aims to provide contribution beyond those achieve on original studies. Due to that, it usually analyse a smaller amount of cases, which can lead to considerations regarding the generalizability that this study has. Metasynthesis is thus an approach that relies on the interpretation of qualitative case studies that had a similar understanding of constructs. In this sense, even though 76 studies were identified over three different databases (Web of Science, Scopus, and EBSCO), the five studies that wee analyzed displayed similarities among them. Something that should be taken into consideration. Nevertheless, the studies were selected accordingly to the inclusion criteria of Hoon (2013) methodology, which grants validity to the selected studies.

Apart from that, we used only two search strings to collect the studies from the databases, with three different keywords being used. Nevertheless, these keywords were very broad, reflecting the approach used at other metasynthesy studies, such as Hoon (2013) and Morais-da-Silva et al. (2016). In this sense, and by following Hoon (2013) protocol, we aimed to reduce the methodological limitations of the meta-synthesis approach, as well as to allow it to be replicated with different samples of studies.

Upon that we state that this meta-synthesis provides a valuable contribution to the field of the digital transformation/industry 4.0 when jointly analyzed with the literature of value. More specifically, the meta-synthesis protocol allowed the researchers to develop the causal networks, the meta-causal network (Figure 1) and the crosscase comparison table (Table 7), which demonstrated that the broader context of industry 4.0 and digital transformation is yet to be explored by studies.

Considering that, future studies need to consider an approach that encompasses value chain and business models to comprehend how value is affected by digital tranforation. The meta-causal network displayed at Figure 1 can be as a starting point to have an analysis performed, thus addressing constructs that were mentioed by the reviewed studies but explored in isolation at their analysis.

As pointed at the study of Pesce et al. (2019), the involvement of multiple stakeholders also leads to topics of regulatory and governance issues, another relationship yet to be explored by studies, as those do affect the way value is created and capture, but were not yet taken into consideration. The same is valid for value capture encompassing the dimensions of social and environmental aspects. As stated on this study, value capture tends to be explored considering the economic dimension, something that was indeed confirmed with the reviewed studies.

Since industry 4.0 literature states the importance and benefitis that digital transformation can create for environmental and social aspects (Kagerman et al., 2013), this is a research stream that should be connected with value aspects, more specifically with value capture aspects of these two dimensions.

On the botton line, studies need to encompass a broader scenario, since industry 4.0 calls for a co-creation of value between the organization and the ecosystem where its inserted (Kagerman et al., 2013; Kiel et al., 2017; Müller et al., 2018), something that still need further development on the literature, especially for value capture aspects where multiple organizations with multiple interests will be inserted.

The development of this meta-synthesis also has a practical implication, since organizations that are looking for digital transformation strategies can use the meta-causal network as a baseline for the development of strategies that would address critical factors that can lead to value creation at industry 4.0.

Value, as we previous mentioned, is one of the most ill defined concepts at the area of management (SánchezFernández \& Iniesta-Bonilla, 2007). And this seems to reflect upon studies related to industry 4.0 , where the aspects of value are yet to be further explored. To proper understand the extend of how aspects of value are affected by digital transformation and industry 4.0 , this metasynthesis, with the findings discussed at the previous sections, and its causal and meta-causal strategies could be a starting point for a better comprehension of this relationship.

\section{REFERENCES}

Arnold, C., Kiel, D., \& Voigt, K. (2017). Innovative business models for the industrial internet of things. BHM Berg- und Hüttenmännische Monatshefte, 162(9), 371-381. https://doi.org/10.1007/s00501-017-0667-7

Arribas, V., \& Alfaro, J. A. (2017). 3D technology in fashion: From concept to consumer. Journal of Fashion Market and Management, 22(2), 240-251. https://doi.org/10.1108/JFMM-10-2017-0114

Baden-Fuller, C., \& Haefliger, S. (2013). Business model and technological innovation. Long Range Planning, 46, 419 426. https://doi.org/10.1016/j.Irp.2013.08.023

Barney, J. B. (1991). Firm resources and sustained competitive advantage. Journal of Management, 17(1), 99-120. https://doi.org/10.1177\%2F014920639101700108 
Cruzara, Takahashi, Sandri \& Cherobim - The impact of digital transformation and industry 4.0 on the aspects of value

Bowman, C., \& Ambrosini, V. (2000). Value creation versus value capture: towards a coherent definition of value in Strategy. British Journal of Management, 11(1), 1-15. https://doi.org/10.1111/1467-8551.00147

Burmeister, C., Lüttgens, D., \& Piller, F. T. (2016). Business model innovation for industry 4.0: Why the "industrial internet" mandates a new perspective on innovation. Die Unternehmung: Swiss Journal of Business Research and Practice, 70(2), 124-152. https://doi.org/10.5771/0042059X-2016-2-124

Cassandras, C. G. (2017). Automating mobility in smart cities. Annual Reviews in Control, 44, 1-8. https://doi.org/10.1016/j.arcontrol.2017.10.001

Davies, I., \& Chambers, L. (2017). Integrating hybridity and business model theory in sustainable entrepreneurship. Journal of Cleaner Production, 177, 378-386. https://doi.org/10.1016/j.jclepro.2017.12.196

Brito, R. P., \& Brito, L. A. L. (2012). Vantagem competitiva, criação de valor e seus efeitos sobre desempenho. RAE - Revista de Administração de Empresas, 52(1), 70-84. https://doi.org/10.1590/S0034-75902012000100006

Docherty, I., Marsden, G., \& Anable, J. (2018). The governance of smart mobility. Transportation Research Part A: Policy and Practice, 115 ,

114-125. https://doi.org/10.1016/j.tra.2017.09.012

Fatorachian, H., \& Kazemi, H. (2018). A critical investigation of Industry 4.0 in manufacturing: theoretical operationalization framework. Production Planning \& Control, 29(8), 633-644. https://doi.org/10.1080/09537287.2018.1424960

Geritz, L. (2016). Design Management as a domain of smart and sustainable enterprise: business modeling for innovation and smart growth in industry 4.0. The International Journal of Entrepreneurship and Sustainability Issues, 3(3), 244268. https://doi.org/10.9770/jesi.2016.3.3(3)

Gregor, T.; Krajcovic, M., \& Wiecek, D. (2017). Smart connected logistics. Procedia Engineering, 192, 265-270. https://doi.org/10.1016/j.proeng.2017.06.046

Grönroos, C. (2008). Service logic revisited: who creates value? And who co-creates? European Business Review, 20(4), 298-314. https://doi.org/10.1108/09555340810886585

Grönroos, C., \& Voima, P. (2013). Critical service logic: making sense of value creation and co-creation. Journal of the Academy of Marketing Science, 41(2), 133-150. https://doi.org/10.1007/s11747-012-0308-3

Helkkula, A., Kelleher, C., \& Pihlström, M. (2012). Characterizing value as an experience: implications for service researchers and managers. Journal of Service Research, 15(1), 59-75. https://doi.org/10.1177/1094670511426897

Hofmann, E., \& Rusch, M. (2017). Industry 4.0 and the current status as well as future prospects on logistics. Computers in Industry, 89, 23-34. https://doi.org/10.1016/j.compind.2017.04.002

Hoon, C. (2013). Meta-synthesis of qualitative case studies: an approach to the building. Organizational Research Methods, 16(4), 522-556. https://doi.org/10.1177/1094428113484969

Ito, N. C., Hayashi, P., Jr., Gimenez, F. A. P., \& Fensterseifer, J. E. (2012). Valor e vantagem competitiva: buscando definições, relações e repercussões. RAC - Revista de Administração Contemporânea, 16(2), 290-307. https://doi.org/10.1590/S1415-65552012000200008

Jerman, A., Erenda, I., \& Bertoncelj, A. (2019). The influence of critical factors on business model at a smart factory: a case study. Business Systems Research Journal, 10(1), 42-52. https://doi.org/10.2478/bsri-2019-0004

Kagerman, H., Wahlster, W., \& Helbig, J. (2013). Recommendations for implementing the strategic initiative Industry 4.0. Final report of the Industry 4.0 Working Group
2013. Frankfurt: Communication Promoters Group of the Industry-Science Research Alliance. https://www.din.de/blob/76902/e8cac883f42bf28536e7e81 65993f1fd/recommendations-for-implementing-industry-40-data.pdf

Khaitan, S. K., \& McCalley, J. D. (2015). Design techniques and applications of cyberphysical systems: a survey. IEEE Systems Journal, 9(2), 350-365. https://doi.org/10.1109/JSYST.2014.2322503

Kiel, D., Arnold, C., \& Voigt, K. (2017). The influence of the industrial internet of things on business models of established manufacturing companies - a business level perspective. Technovation, 68, 4-19. https://doi.org/10.1016/j.technovation.2017.09.003

Lecocq, X., Demil, B., \& Warnier, V. (2006). Le business model, un outil d'analyse stratégique. L'Expansion Management Review, 123, 96-109. https://doi.org/10.3917/emr.123.0096

Liao, Y., Deschamps, F., Loures, E. de F. R., \& Ramos, L. F. P. (2017). Past, present and future of Industry 4.0 - a systematic literature review and research agenda proposal. International Journal of Production Research, 55(12), 36093629. https://doi.org/10.1080/00207543.2017.1308576

Lichtenhaler, U. (2017). Shared value innovation: linking competitiveness and societal goals in the context of digital transformation. International Journal of Innovation and Technology Management (IJITM), 14(4), 1-14. https://doi.org/10.1142/S0219877017500183

Lilis, G., \& Kayal, M. (2018). A secure and distributed message oriented middleware for smart building applications. Automation in Construction. 86, 163-175. https://doi.org/10.1016/j.autcon.2017.10.030

Marx, K. (1990). Capital: a critique of political economy. London: Penguin Books. (Original published in: 1867).

Morais-da-Silva, R. L., Takahashi, A. R. W., \& Segatto, A. P. (2016). Scaling up social innovation: a meta-synthesis. Mackenzie Management Review (RAM), 17(6), 134-163. https://doi.org/10.1590/167869712016/administracao.v17n 6p134-163

Miles, M. B., \& Huberman, A. M. (1994). Qualitative data analysis: An expanded sourcebook. 2 ed. London: Sage.

Mishra, D. P., Heide, J. D., \& Sort, S. G. (1998). Information asymmetry and levels of agency relationships. Journal of Marketing Research, 35(3), 277-295. https://doi.org/10.2307/3152028

Müller, J. M. (2019). Business model innovation in small- and medium-sized enterprises: Strategies for industry 4.0 providers and users. Journal of Manufacturing Technology Management, $\quad 30(8), \quad 1127-1142$. https://doi.org/10.1108/JMTM-01-2018-0008

Müller, J. M., Buliga, O., \& Voigt, K. (2018). Fortune favors the prepared: How SMEs approach business model innovations in Industry 4.0. Technological Forecast \& Social Change, 132, 2-17. https://doi.org/10.1016/j.techfore.2017.12.019

Oesterreich, T., \& Teuteberg, G. (2016). Understanding the implications of digitisation and automation in the context of Industry 4.0: A triangulation approach and elements of a research agenda for the construction industry. Computers in Industry, https://doi.org/10.1016/i.compind.2016.09.006

$83,121-139$

Orlandi, L. B. (2016). Organizational capabilities in the digital era: Reframing strategic orientation. Journal of Innovation \& Knowledge, https://doi.org/10.1016/j.jik.2016.01.002

Osterwalder, A., \& Pigneur, Y. (2010). Business model generation: a handbook for visionaries, game changers, and challengers. Hoboken NJ: John Wiley and Sons. 
Park, C., Kim, H., \& Yong, T. (2017). Dynamic characteristics of smart grid technology acceptance. Energy Procedia, 128, 187-193. https://doi.org/10.1016/i.egypro.2017.09.040

Pesce, D., Neirotti, P., \& Paoilucci, E. (2019). When culture meets digital platforms: value creation and stakeholder's alignment in big data use. Current Issues in Tourism, 22(15), https://doi.org/10.1080/13683500.2019.1591354

Peteraf, M. A. (1993). The cornerstones of competitive advantage: a resource based view. Strategic Management Journal, 14(3), 179-191.

Pitelis, C. (2009). The co-evolution of organizational value capture, value creation and sustainable advantage. Organization Studies, $\quad 30(10), \quad 1115-1139$. https://doi.org/10.1177/0170840609346977

Porter. M. E. (1996). What is Strategy? Harvard Business Review, 74(6), 61-78.

Porter, M. E., \& Heppelmann, J. E. (2015). How smart, connected products are transforming companies Harvard Business Review, 93(10), 96-114.

Porter, M. E., \& Millar, V. E. (1985). How information gives you competitive advantage. Harvard Business Review. July. https://hbr.org/1985/07/how-information-gives-youcompetitive-advantage

Rumelt, R. P. (1984). Towards a strategic theory of the firm. In R. B. Lamb (Ed.), Competitive strategic management (pp. 556570). Prentice Hall: Englewood Cliffs.

Sánchez-Fernánzes, R., \& Iniesta-Bonilla, Á. M. (2007). The concept of perceived value: a systematic review of the research. Marketing Theory, 7(4), 427-451. https://doi.org/10.1177/1470593107083165

Shin, D. (2017). An exploratory study of innovation strategies of the internet of things SMEs in South Korea. Asia Pacific Journal of Innovation and Entrepreneurship, 11(2), 171189. https://doi.org/10.1108/APJIE-08-2017-025

Spath, D. O., Ganschar, S., Gerlach, M., Hammerle, T., Krause, T., \& Schlund, S. (2013). Produktionsarbeit Der ZukunftIndustrie 4.0 [Production Work of the Future-Industry 4.0]. Stuttgart: Fraunhofer IAO.

Teece, D. J. (2014). A dynamic capabilities-based entrepreneurial theory of the multinational enterprise. Journal of International Business Studies, 45, 8-37. https://doi.org/10.1007/978-1-137-54471-1 9

Teece, D. J. (2018a). Business models and dynamic capabilities. Long Range Planning, 51(1), 40-49. https://doi.org/10.1016/j.Irp.2017.06.007

Teece, D. J. (2018b). Profiting from technological innovation the digital economy: Enabling technologies standards, and licensing models in the wireless world. Research Policy, 47(8), https://doi.org/10.1016/j.respol.2017.01.015

Teece, D. J., \& Linden, G. (2017). Business models, value capture, and the digital enterprise. Journal of Organization Design, 6(8). https://doi.org/10.1186/s41469-017-0018-x

Vieira, E. S., \& Gomes, J. A. N. F. (2009). A comparison of Scopus and Web of Science for a typical university. Scientometrics, 81, 587-600. https://doi.org/10.1007/s11192-009-2178-0

Weber, R. H. (2013). Internet of things - Governance quo vadis? Computer Law and Security Review, 19(4), 341-347. https://doi.org/10.1016/j.clsr.2013.05.010

$\mathrm{Xu}$, L., Xu, E., \& Li, L. (2018). Industry 4.0: state of the art and future trends. International Journal of Production Research, 56(8), https://doi.org/10.1080/00207543.2018.1444806

Zeng, J., Simpson, C., \& Dang, B. (2017). A process model of dynamic capability development: evidence from the Chinese manufacturing sector. Management and

\begin{tabular}{l}
$\begin{array}{l}\text { Organizational Review, } \\
\text { https://doi.org/10.1017/mor.2016.42 }\end{array}$ \\
\hline
\end{tabular}




\section{CONTEXTUS}

REVISTA CONTEMPORÂNEA DE ECONOMIA E GESTÃO

\section{CONTEXTUS}

CONTEMPORARY JOURNAL OF ECONOMICS AND

MANAGEMENT.

ISSN 1678-2089

\section{ISSNe 2178-9258}

1. Economics, Administration and Accounting - Journal

2. Federal University of Ceara. Faculty of Economics,

Administration, Actuaries and Accounting

\section{FACULTY OF ECONOMICS, ADMINISTRATION, ACTUARIES AND ACCOUNTING}

University Av. - 2486, Benfica

60020-180, Fortaleza-CE

BOARD: Paulo Rogério Faustino Matos Danielle Augusto Peres

Website: www.periodicos.ufc.br/contextus

E-mail: revistacontextus@gmail.com

CONTEXTUS

REVISTA CONTEMPORANEA

DE ECONOMIA E GESTÃO

UNIVERSIDADE

FEDERAL

DO CEARÁ

FACULDADE

DE ECONOMIA,

ADMINISTRAC̄ÃO,

ATUÁRIA

E CONTABILIDADE

\section{EDITOR-IN-CHIEF}

Diego de Queiroz Machado (UFC)

\section{ASSISTANT EDITORS}

Alane Siqueira Rocha (UFC)

Márcia Zabdiele Moreira (UFC)

\section{ASSOCIATE EDITORS}

Alessandra de Sá Mello da Costa (PUC-Rio)

Andrew Beheregarai Finger (UFAL)

Armindo dos Santos de Sousa Teodósio (PUC-MG)

Brunno Fernandes da Silva Gaião (UEPB)

Carlos Enrique Carrasco Gutierrez (UCB)

Elionor Farah Jreige Weffort (FECAP)

Gabriel Moreira Campos (UFES)

Guilherme Jonas Costa da Silva (UFU)

Henrique César Muzzio de Paiva Barroso (UFPE)

Jorge de Souza Bispo (UFBA)

Keysa Manuela Cunha de Mascena (UNIFOR)

Minelle Enéas da Silva (La Rochelle, France)

Pedro Jácome de Moura Jr. (UFPB)

Rafael Fernandes de Mesquita (IFPI)

Rosimeire Pimentel (UFES)

Susana Jorge (UC, Portugal)

Thiago Henrique Moreira Goes (UFPR)

\section{EDITORIAL BOARD}

Ana Sílvia Rocha Ipiranga (UECE)

Conceição de Maria Pinheiro Barros (UFC)

Danielle Augusto Peres (UFC)

Diego de Queiroz Machado (UFC)

Editinete André da Rocha Garcia (UFC)

Emerson Luís Lemos Marinho (UFC)

Eveline Barbosa Silva Carvalho (UFC)

Fátima Regina Ney Matos (ISMT)

Mario Henrique Ogasavara (ESPM)

Paulo Rogério Faustino Matos (UFC)

Rodrigo Bandeira-de-Mello (FGV-EAESP)

Vasco Almeida (ISMT)

\section{SCIENTIFIC EDITORIAL BOARD}

Alexandre Reis Graeml (UTFPR)

Augusto Cezar de Aquino Cabral (UFC)

Denise Del Pra Netto Machado (FURB)

Ednilson Bernardes (Georgia Southern University)

Ely Laureano Paiva (FGV-EAESP)

Eugenio Ávila Pedrozo (UFRGS)

Francisco José da Costa (UFPB)

Isak Kruglianskas (FEA-USP)

José Antônio Puppim de Oliveira (UCL)

José Carlos Barbieri (FGV-EAESP)

José Carlos Lázaro da Silva Filho (UFC)

José Célio de Andrade (UFBA)

Luciana Marques Vieira (UNISINOS)

Luciano Barin-Cruz (HEC Montréal)

Luis Carlos Di Serio (FGV-EAESP)

Marcelle Colares Oliveira (UFC)

Maria Ceci Araujo Misoczky (UFRGS)

Mônica Cavalcanti Sá Abreu (UFC)

Mozar José de Brito (UFL)

Renata Giovinazzo Spers (FEA-USP)

Sandra Maria dos Santos (UFC)

Walter Bataglia (MACKENZIE)
DORA Francisco Declaration on Research Assessment (DORA).

ABEC Contextus is associated with the Brazilian Association of Scientific Editors.
This work is licensed under a Creative Commons Attribution - NonCommercial 4.0 International license. 